\title{
Effectiveness of Estradiol Valerate on Sex Reversion in Astyanax altiparanae (Characiformes, Characidae)
}

\author{
Jaqueline Cristina de Bem ${ }^{1}$, Carmem Silvia Fontanetti ${ }^{1}$, José Augusto Senhorini ${ }^{2}$ and \\ Patricia Pasquali Parise-Maltempi ${ }^{*}$ \\ ${ }^{I}$ Departamento de Biologia; Instituto de Biociências de Rio Claro; Universidade Estadual Paulista Júlio de \\ Mesquita Filho; Rua 24A, 1515; 13506-900; Rio Claro - SP - Brasil . ${ }^{2}$ Centro Nacional de Pesquisa e Conservação \\ de Peixes Continentais; Instituto Chico Mendes de Conservação da Biodiversidade; Rod. Prefeito Euberto Nemésio \\ Pereira de Godoy, Km 6,5; 13630-970; Pirassununga - SP - Brasil
}

\begin{abstract}
The objective of this study was to evaluate the effectiveness of estradiol valerate in an attempt to feminize the male Astyanax altiparanae. One thousand newly-hatched larvae were randomly distributed in four incubators. During a period of 30 days, estradiol valerate was administered in different dosages (20, 40, and $80 \mathrm{mg} / \mathrm{kg}$ of diet); the control group did not receive hormone in the diet. After 161 days of hatching, biometry was performed on 50 fishes per treatment group, and the gonads were analyzed. The hormone treatments were effective in feminizing A. altiparanae, achieving 70-76\% of the desired sex, while the control treatment had $44 \%$ females. The hormone did not affect the growth of fish.
\end{abstract}

Key words: Astyanax altiparanae, Characidae, Feminization, Sex Reversion, Estrogen

\section{INTRODUCTION}

Brazil has a wide diversity of species potentially suitable for breeding in captivity. Astyanax altiparanae (Garutti and Britski 2000) is one among these, which is gaining the attention of researchers and producers due to the following characteristics: high survival rate of larvae and juveniles; rapid growth; omnivorous; easy acceptance of artificial food; tasty meat; high demand as live bait by fishermen (Ihering and Azevedo 1936; Cemig/Cetec 2000; Sales and Firetti 2003; Hayashi et al. 2004); and forage for various predators (Nomura 1975; Esteves 1996).

During the reproductive period of A. altiparanae, clear morphological differences exist between the males and females. Females, in addition to being larger with a more rounded body, often grow earlier than the males (Porto-Foresti et al. 2001; Sato et al. 2006). Thus, increased production of female A. altiparanae is advantageous to fish producers. Navarro et al. (2006) found that sex influenced the morphometry and somatic indices of Astyanax scabripinnis under rearing conditions; specifically, females reared separately from the males had better growth compared to other treatments in the presence of males. These authors observed that females reared separately from the males also had better reproductive performance.

In addition to the noticeable increased growth rate of one sex over the other, which is one of the main advantages obtained by monosex rearing, depending on the species, the use of monosex rearing may also have the following advantages: containment of energy costs with reproductive activity; reducing aggressive interactions; greater

\footnotetext{
*Author for correspondence: parise@rc.unesp.br
} 
uniformity of size at harvest; and reducing the risk of environmental impact through fish escape (Beardmore et al. 2001).

The present study aimed to verify the effectiveness of estradiol valerate on tetra A. altiparanae feminization with the intention to contribute data that could advance the knowledge about the production and standardization of a sex reversion technique in native fish.

\section{MATERIALS AND METHODS}

A total of 120 breeders of A. altiparanae, 30 females and 90 males, captured in captivity from CEPTA were used in this study. The method employed to induce the breeding was hypophysation (Ihering and Azevedo 1934), in semi-natural breeding conditions. The specimens received one dose of crude carp pituitary extract (CCPE) at concentration of $3 \mathrm{mg} / \mathrm{kg}$ of fish, injected into the pectoral fin base. A total of six plastic screen cages ( $40 \times 40 \times 25 \mathrm{~cm})$ were used with five females and 15 males each. These cages were distributed in two horizontal incubators with constant circulation of water (35 liters of water capacity). Spawning and fertilization of the breeders were performed in a natural way.

Initially, 1,000 newly-hatched larvae were distributed in four horizontal incubators with 35 liters of water capacity, but were kept in 25 liters of water with 10 larvae/liter. The water in the incubators was maintained under constant artificial aeration with renewal 10 times a day. The dissolved oxygen, $\mathrm{pH}$, and water temperature were measured daily; the water alkalinity was evaluated weekly. Each incubator represented a different treatment as follows: control (no added hormone in the diet) and treatments with the administration of estradiol valerate in doses of 20,40 , and 80 $\mathrm{mg} / \mathrm{kg}$ feed.

Three days after hatching (DAH) larvae were fed for 20 days with Artemia salina nauplii at an initial density of 500 nauplii/larvae/day, divided into three meals ( 8 h $30 \mathrm{~min}, 14 \mathrm{~h} 30 \mathrm{~min}$, and $17 \mathrm{~h} 30$ $\mathrm{min}$ ), in the case of some initial rejection of artificial diet. This natural diet was gradually withdrawn from the fish feed. At $3 \mathrm{DAH}$, the larvae also began to receive an artificial diet with $35 \%$ crude protein, containing the feminizing hormone specific to each treatment, except for the control diet, which consisted only of balanced feed with $35 \%$ crude protein. The artificial diets were fed ad libitum six times a day.To prepare the diet with the hormone, estradiol valerate $(20 \mathrm{mg}, 40$ $\mathrm{mg}$, or $80 \mathrm{mg}$ ) was dissolved in $500 \mathrm{~mL}$ of ethanol and mixed into a pound of powder rations. Diets were dried naturally in a closed environment without ventilation. Once dry, the rations were divided into portions, packed in plastic bags, and kept in a freezer, removing only the portions for immediate consumption.

Hormonal treatment lasted 30 days; however, the experiment was extended up to $161 \mathrm{DAH}$ to await the growth of juveniles, thus permitting the removal of the gonads to evaluate the efficiency of the hormonal treatment. At this stage, the fishes were fed balanced diets with $35 \%$ crude protein ad libitum. Throughout the experiment, the decrease in the density of the fishes in the experimental units was allowed so that the individuals could grow in an appropriate environment of densities, keeping always the same number of individuals among the treatments. As a result, fish mortality was not evaluated in this study.

After the growth of the juveniles, 50 fishes from each of the four treatments were randomly collected (a total of 200 individuals at $161 \mathrm{DAH}$ ). These individuals were insensibilized and sacrificed by thermal shock at $2^{\circ} \mathrm{C}$ and necropsied through an incision in the ventral region from the anus to the operculum to expose the organs and for identification of the sex of the individuals. The sex of tetras was determined by analyzing the presence of secondary sexual characteristics, such as females with a swollen abdomen and increased irrigation by blood vessels in this region of the body, and males with an anal fin rough to the touch; also, some gonad parameters were evaluated, such as color, transparency, vascularity, and observation of oocytes with the naked eye. Moreover, the sex of tetras was determined and/or confirmed in all the individuals by the carmine acetic method of Guerrero and Shelton (1974), and validated for juvenile Nile tilápia according to Wassermann and Afonso (2002). For microscopic examination of the gonads, a light microscope (Nova 107) was used. Some gonads of these individuals at $161 \mathrm{DAH}$ were selected and photographed by light microscopy (Olympus BX51 and Olympus DP71) for simple illustration of the differences in gonadal morphology between the females and males.

Fishes collected for the sex identification were submitted to biometry. To obtain the total weight 
of the individual, an analytical balance accurate to $0.0001 \mathrm{~g}$ and calipers $(\mathrm{mm})$ to measure the total length was used.

To check if the proportion of the females was higher than the males in each of the four treatments $(0,20,40$, and $80 \mathrm{mg} / \mathrm{kg}$ diet $)$, the $\mathrm{Z}$ test for proportions was used. The analysis of variance (ANOVA) for weight and length variables, assuming the use of a completely randomized design with treatments in a hierarchical scheme with the factors dose and sex within each dose level were used. Subsequently, the average number of the females compared with the males in each treatment was compared using the $\mathrm{F}$ test and a significance level $\mathrm{P}=0.05$.

\section{RESULTS}

The values of dissolved oxygen, $\mathrm{pH}$, alkalinity, and water temperature did not vary among the four treatments throughout the experiments. The dissolved oxygen values ranged between 6.0 and $7.0 \mathrm{mg} / \mathrm{L}$, the water $\mathrm{pH}$ ranged between 5.5 and 6.5 , and alkalinity remained at $20 \mathrm{mg} / \mathrm{L}$. The daily temperature fluctuated greatly for all the treatments, with an average of $21.8^{\circ} \mathrm{C} \pm \mathrm{sd}=2$. The proportion of the females to the males did not differ significantly in the control treatment $(\mathrm{P}>0.05)$, but was higher $(\mathrm{P}<0.05)$ when reared at hormone levels of 20, 40, and $80 \mathrm{mg}$. However, increasing the dosage from 20 to $80 \mathrm{mg}$ did not significantly change the proportion of the females (Table 1).

Regarding the length and weight characteristics, there were no significant differences between the averages of four treatments, but females were larger and heavier than the males $(\mathrm{P}<0.05)$ in the control group and 20 and $40 \mathrm{mg}$ dosages; at the maximum dosage of $80 \mathrm{mg}$, females and males showed similar growth ( $\mathrm{P}>0.05$; Table 2$)$.

Table 1 - Sex ratio of the A. altiparanae species in the treatment without hormone (control treatment) and with estrogen estradiol valerate in different amounts, after 161 days of fish life.

\begin{tabular}{ccc}
\hline Treatment & Female & Male \\
\hline Control & $0.44^{\mathrm{a}}$ & $0.56^{\mathrm{a}}$ \\
$20 \mathrm{mg} / \mathrm{kg}$ & $0.70^{\mathrm{a}}$ & $0.30^{\mathrm{b}}$ \\
$40 \mathrm{mg} / \mathrm{kg}$ & $0.76^{\mathrm{a}}$ & $0.24^{\mathrm{b}}$ \\
$80 \mathrm{mg} / \mathrm{kg}$ & $0.76^{\mathrm{a}}$ & $0.24^{\mathrm{b}}$ \\
\hline
\end{tabular}

${ }^{11}$ Proportions followed by different letters in the same row $\operatorname{differ}(\mathrm{P}<0.05)$ by $\mathrm{Z}$ test for proportions.

Table 2 - Mean and standard error (s.e.) of length and weight of A. altiparanae per treatment and per sex with different hormonal dosages and control, after 161 days of fish life.

\begin{tabular}{|c|c|c|c|c|c|c|}
\hline \multirow{2}{*}{ Treatment } & \multicolumn{2}{|c|}{ Female } & \multicolumn{2}{|c|}{ Male } & \multicolumn{2}{|c|}{ Total } \\
\hline & Mean & s.e. & Mean & s.e. & Mean & s.e. \\
\hline \multicolumn{7}{|c|}{ Length (cm) } \\
\hline Control & $6.00^{\mathrm{a}}$ & 0.16 & $5.30^{\mathrm{b}}$ & 0.14 & $5.65^{A}$ & 0.11 \\
\hline $20 \mathrm{mg} / \mathrm{kg}$ & $5.95^{\mathrm{a}}$ & 0.13 & $5.50^{\mathrm{b}}$ & 0.19 & $5.72^{\mathrm{A}}$ & 0.11 \\
\hline $40 \mathrm{mg} / \mathrm{kg}$ & $5.98^{\mathrm{a}}$ & 0.12 & $5.40^{\mathrm{b}}$ & 0.21 & $5.69^{\mathrm{A}}$ & 0.12 \\
\hline $80 \mathrm{mg} / \mathrm{kg}$ & $5.72^{\mathrm{a}}$ & 0.12 & $5.46^{\mathrm{a}}$ & 0.21 & $5.59^{\mathrm{A}}$ & 0.12 \\
\hline Total & 5.91 & 0.07 & 5.41 & 0.10 & 5.66 & 0.06 \\
\hline \multicolumn{7}{|c|}{ Weight (g) } \\
\hline Control & $3.09^{\mathrm{a}}$ & 0.25 & $1.90^{b}$ & 0.22 & $2.50^{\mathrm{A}}$ & 0.16 \\
\hline $20 \mathrm{mg} / \mathrm{kg}$ & $3.07^{\mathrm{a}}$ & 0.20 & $2.41^{\mathrm{b}}$ & 0.30 & $2.74^{\mathrm{A}}$ & 0.18 \\
\hline $40 \mathrm{mg} / \mathrm{kg}$ & $3.19^{\mathrm{a}}$ & 0.19 & $2.29^{b}$ & 0.33 & $2.74^{\mathrm{A}}$ & 0.19 \\
\hline $80 \mathrm{mg} / \mathrm{kg}$ & $2.78^{\mathrm{a}}$ & 0.19 & $2.33^{\mathrm{a}}$ & 0.33 & $2.56^{\mathrm{A}}$ & 0.19 \\
\hline Total & 3.03 & 0.10 & 2.23 & 0.15 & 2.63 & 0.09 \\
\hline
\end{tabular}

In this study, gonads of the female A. altiparanae were observed at different ovarian development stages. The gonads showed large caliber blood vessels which were thick and dense, traversing and branching into thinner portions throughout the gonad (Fig. 1A). Female gonads were observed to 
have the clusters of oocytes at different development stages in the same ovary (Fig. 1B-D). There was evidence of immature oocytes of different sizes (Fig. 1B) and mature oocytes of larger sizes and filled with gray yolk granules (Fig. 1C). Some oocyte atresia was identified (Fig. 1D). In a few females in the 20 and $80 \mathrm{mg} / \mathrm{kg}$ treatment groups, in addition to the oocytes at various stages of development occupying almost the entire gonad, a group of small cells in the peripheral regions of the gonad were observed which were similar to the structures observed in the male gonads (Fig. 1E). Testes (Fig. 1F) were present as massive and compact structures formed by small, filiform cells with the typical appearance of sperm (Fig. 1G-H).
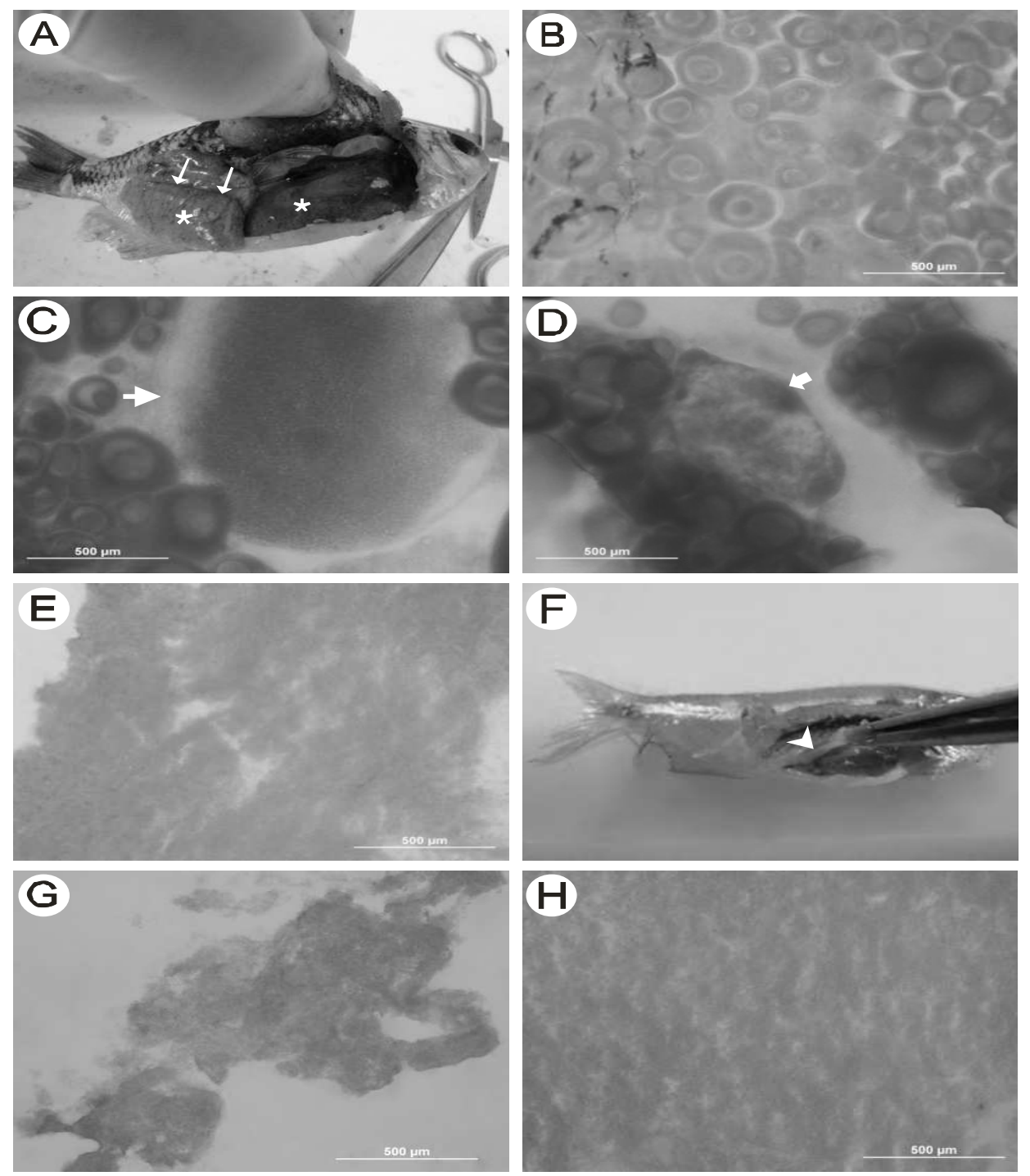

Figure 1 - Adult/mature female Astyanax altiparanae (A), the gonad is indicated by asterisks (*), where it indicates extensive branching of blood vessels $\leftrightarrow$ ). Gonads of female A. altiparanae (B E) stained with acetic carmine, which were observed regions populated by oocytes at different stages of development (B) and may indicate oocytes in a more advanced stage of vitellogenesis $(\vec{b}$ in $\mathrm{C}$ ), and the presence of cells in atresia stage $(\Rightarrow$ in D). A differentiated structure (E) was observed in peripheral region of the gonad, resembling the structure of male gonads. Adult male $A$. altiparanae $(\mathrm{F})$, where the arrow ( $>$ in F) indicates the fish gonad. Gonads of male A. altiparanae $(\mathrm{G}-\mathrm{H})$ stained with acetic carmine, where compact structures were observed with small cells which were similar to sperm structure in initial formation. The figures $\mathrm{A}$ and $\mathrm{F}$ represent individuals of control treatment. The figures $\mathrm{C}, \mathrm{D}$ and $\mathrm{H}$ belong to the treatment with $20 \mathrm{mg} / \mathrm{kg}$ diet. The figures $B$ and $E$ correspond to the treatment with $40 \mathrm{mg} / \mathrm{kg}$ diet. The figure $\mathrm{G}$ is equivalent to the treatment with $80 \mathrm{mg} / \mathrm{kg}$ diet. 


\section{DISCUSSION}

The result of up to $76 \%$ females of A. altiparanae in this work was a significant and unprecedented finding for native species of the Characidae family. Moreover, this result was close to that obtained by Amaral et al. in 2008, which also showed effective results in the feminization (88.2\% female) of another native species, the catfish Rhamdia quelen of the Heptapteridae family. Studies on the feminization of a native species, Odontesthes bonariensis (Strussmann et al. 1996), and an exotic species, Oreochromis aureus (Mélard 1995), obtained excellent results of $100 \%$ females. Scott et al. (1989) obtained good results with the feminization of Oreochromis niloticus species (51.6 and $83.9 \%$ in two different tests), while in a study with the same species, Bombardelli and Hayashi (2005) obtained inefficient results.

In contrast to androgens, obtaining successful treatment with estrogen has been more difficult to achieve (McAndrew 1993) because androgens are more potent sex changing agents than estrogens, and higher doses of estrogens are required to feminize the fish effectively (Hendry et al. 2003). However, in A. altiparanae, the use of $20 \mathrm{mg}$ of hormone generated the same result as the treatment with a hormonal dosage four times higher $(80 \mathrm{mg})$, making the $20 \mathrm{mg}$ estradiol valerate most advantageous dosage. Furthermore, it should be considered that even when using high doses, in some species such as carp, the use of estrogen was completely ineffective (Komen and Richter 1993), indicating that the hormone efficiency was not directly linked to high hormonal doses. The study of different hormone dosages could be of great interest to establish a better result in sex reversion of fish, as well as control of environmental factors, which according to Beardmore et al. (2001), influenced the sex rate of fish species, for example, temperature (Abucay et al. 1999) and pH (Rubin 1985).

The timing and duration of the treatment are of critical importance for inducing the sex reversion in fish (Piferrer 2001). In this study, the estradiol valerate was administered at early stages of larval development and extended for a prolonged period to ensure the effectiveness of the treatment, whereas in general, the most sensitive period of sex reversion was at a time just prior to, or concomitant with the initial histological differentiation of the primitive gonad (Hunter and
Donaldson 1983). Moreover, it is known that the results of the feminization by estrogens, in contrast to the treatment with androgens, show a better response in younger larvae (Bombardelli and Hayashi 2005), as shown for the species Oncorhynchus kisutch (Piferrer and Donaldson 1989) and O. niloticus (Bombardelli and Hayashi 2005). However, to avoid the indiscriminate use of sex hormone, it is necessary to know the sexual differentiation period of the species in question so that the hormone is applied only when deemed appropriate.

In the results of this study, there were significant differences in length and weight factors between the females and males at $161 \mathrm{DAH}$ in the control group, and those treated with 20 and $40 \mathrm{mg}$ of estradiol valerate; this was already expected due to the knowledge that females typically were larger in size than the males (Porto-Foresti et al. 2001; Sato et al. 2006). However, when treated with 80 $\mathrm{mg}$ of hormone, the fishes exhibited similar characteristics of length and weight regardless of sex.

Despite the higher percentage of the females in the hormonal treatments compared to the controls, the final average weight and length of the fishes after the four treatments showed no significant difference $(\mathrm{P}>0.05)$. From the data obtained, it could be concluded that the hormone did not affect the growth of the fish. One should take into account, however, that at the end of this experiment, the average weight and length of the fishes were lower in relation to the size that this species could reach. In addition, most of the fish were still sexually immature. This delay was probably related to large variations in the temperature, with the low average daily temperature for optimal growth of this species between 25 and $28^{\circ} \mathrm{C}$ (Porto-Foresti et al. 2005). Thus, despite the statistical differences in weight and length factors found between the sexes in the control group, and treatment with 20 and $40 \mathrm{mg}$ of hormone, there was the possibility that by the end of the experiments, the fishes had not yet developed sufficiently to the point of exhibiting one of the most obvious features of sexual dimorphism for this species: the larger size of the females compared with the males.

Concerning to the morphology of A. altiparanae gonads, all the individuals of the experiments showed pairs and elongated structures situated near the muscles in the dorsolateral direction. The structures parallel to the swim bladder were 
separated from one another, fusing into its caudal part near the genital pore, similar to the characteristics described for the species Astyanax bimaculatus (Nomura 1975; Pelizaro 1980; Agostinho et al. 1984; Andrade et al. 1985; Garutti 1989; Bazzoli et al. 1998), and also resembling other species of the genus (Nomura 1975; Barbieri 1992; Veregue and Orsi 2003; Melo et al. 2005).

Despite the absence of detailed histological studies which proved the presence of intersex gonads in this study, the evidence of possible male structures on the periphery of some ovaries corroborated the action of estradiol valerate in sex reversion of the species under study because the evidence was noted in the individuals that received the hormone. According to Devlin and Nagahama (2002), incomplete sex transformations are regularly observed with steroid treatments in the fishes, such that the development of both testicular and ovarian tissue occurs in the same individual. Also, according to these authors, in gonochorists species it is difficult to determine whether or not intersexuality arises from insufficient treatment (dosage, duration, or timing) or because the particular species is unable to fully respond to exogenous hormone treatment. Sá et al. (2008) observed intersexuality in wild species gonads of A. scabripinnis and although not proven, the authors suggested the possible action of toxic agents in the environment.

The analysis of the A. altiparanae gonads showed the presence of oocytes at different development stages in the same gonad, confirming the asynchrony of this process for the species, as observed by Marcon (2008) for the A. bimaculatus species, and Drummond (1996), Miranda (1996), and Pereira-Filho (2000) for other species of the genus Astyanax. The asynchronous ovary is characteristic of species that spawn several times during the year and have a prolonged reproductive period (Wallace and Selman 1981; De Vlaming 1983).

The feminization rates obtained in this study could have been better if the ontogenic period of this species was known. It is important to know the sexual differentiation period of this specie to determine exact time and duration of the treatment. This study could be supplemented considering a greater control of environmental factors, such as temperature, to help the growth of the individuals. It would be interesting to use other concentrations of estrogen, and even the use of other estrogens for the feminization of the fishes, such as $17 \beta$-estradiol. Beyond that, it is also recommended to evaluate the mortality rate of the individuals as well as a detailed study of the fishes growth subjected to the feminizing hormone.These new data could help to develop a feminization protocol of these native specie.

Based on the results, it was concluded that estradiol valerate was effective in increasing the proportion of female A. altiparanae, reaching 70$76 \%$ of the desired sex without affecting the growth of this species.

\section{ACKNOWLEDGEMENTS}

The authors thank the CEPTA/ICMBio (Centro Nacional de Pesquisa e Conservação de Peixes Continentais) for providing the fish and the physical structure for this study, and also the collaboration of its researchers, in particular the laboratory technician, João dos Santos Caetano Neto, and the researcher, Rita Gimenes Alcântara Rocha. Thanks to Professor Dr. César Gonçalves de Lima for his assistance in statistical analysis; Professor Dr. Evoy Zaniboni Filho for his valuable criticism and revision of the text; the CAPES (Coordenação de Aperfeiçoamento de Nível Superior) to Masters scholarship for J. C. DE BEM and FUNDUNESP (Fundação para o Desenvolvimento da UNESP) for funding of materials for this research.

\section{REFERENCES}

Abucay JS, Mair GC, Skibinski DOF, Beardmore JA. Environmental sex determination: the effect of temperature and salinity on sex ratio in Oreochromis niloticus L. Aquaculture. 1999; 173: 219-234.

Agostinho CA., Molinari S, Agostinho A, Verani, J. Ciclo reprodutivo e primeira maturação sexual de fêmeas do lambari Astyanax bimaculatus (L.) (Osteichtyes-Characidae) do rio Ivaí. Estado do Paraná. Rev. Bras. Biol. 1984; 44: 31-6.

Amaral HJr, Nunes MFS, Garcia S. Análise de diferentes dosagens de hormônio na ração, para definição de um protocolo de feminilização do jundiá Rhamdia quelen. Rev. Electrón. Vet. 2008; 9 (12): 17.

Andrade DR, Godinho HP, Ribeiro SP, Castro, EFT. Ciclo reprodutivo anual de lambaris Astyanax bimaculatus (Linnaeus, 1758) em viveiros. Arq. Bras. Med. Vet. Zootec. 1985; 37 (5): 435-447. 
Barbieri, G. Biologia de Astyanax scabripinnis paranae (Characiformes, Characidae) do ribeirão do Fazzari. II. Aspectos quantitativos da reprodução. Rev. Bras. Biol. 1992; 52 (4): 589-596.

Bazzoli N, Mesquita TL, Santos GB, Rizzo E. Análise comparativa da reprodução de Astyanax bimaculatus (Pisces, Characidade) nos reservatórios de Furnas, Marimbondo e Itumbiara. BioSystems. 1998; 6 (6): 99-112.

Beardmore JA, Mair GC, Lewis RI. Monosex male production in finfish as exemplified by tilapia: applications, problems, and prospects. Aquaculture. 2001; 197: 283-301.

Bombardelli RA, Hayashi C. Masculinização de larvas de tilápia do Nilo (Oreochromis niloticus L.) a partir de banhos de imersão com $17 \alpha$-metiltestosterona. Rev. Bras. Zootec. 2005; 34 (2): 365-372.

CEMIG/CETEC. Guia ilustrado de peixes da bacia do Rio Grande. Companhia Energética de Minas Gerais; Fundação Centro Tecnológico de Minas Gerais. Belo Horizonte: CEMIG/CETEC; 2000. 141 p.

De Vlaming VL. Oocyte development patterns and hormonal involvement among teleosts. In: Rankin JC, Pitcher TJ, Duggon RT, editors. Control processes in fish physiology. London: Croolm Helm; 1983. p. 176-199.

Devlin RH, Nagahama Y. Review article: Sex determination and sex differentiation in fish: an overview of genetic, physiological, and environmental influences. Aquaculture. 2002; 208: 191-364.

Drummond CD. Folículo pós-ovulatório de lambari Astyanax bimaculatus lacustris (Pisces, Characidae) submetido a desova induzida: estudo histológico e ultra-estrutural [M.Sc. Thesis]. Belo Horizonte, Brasil: Universidade Federal de Minas Gerais; 1996.

Esteves KE. Feeding ecology of three Astyanax species (Characidae, Tetragonopterinae) from a floodplain lake of Mogi-Guaçú-river, Parana river basin, Brazil. Environ. Biol. Fishes. 1996; 46 (1): 83-101.

Garutti V. Contribuição ao conhecimento reprodutivo de Astyanax bimaculatus (Ostariophysi, Characidae), em cursos de água da Bacia do Rio Paraná. Rev. Bras. Biol. 1989; 49 (2): 489-495.

Garutti V, Britski HA. Descrição de uma espécie nova de Astyanax (Teleostei: Characidae) da bacia do alto rio Paraná e considerações sobre as demais espécies do gênero na bacia. Comun. Mus. Ciênc. Tecnol. PUCRS, Zool. 2000; 13: 65-88.

Guerrero RD, Shelton WL. An acetato-carmine squash technique for sexing juvenile fishes. Prog. Fish. Cult. 1974; 36 (1): 56.

Hayashi C, Meurer F, Boscolo WR, Lacerda CHF, Kavata LCB. Frequência de arraçoamento para alevinos de lambari do rabo-amarelo (Astyanax bimaculatus). Rev. Bras. Zootec. 2004; 33 (1): 21-6.
Hendry CI, Martin-Robichaud DJ, Benfey TJ. Hormonal sex reversal of Atlantic halibut (Hippoglossus hippoglossus L.). Aquaculture. 2003; 219: 769-781.

Hunter GA, Donaldson EM. Hormonal sex control and its application to fish culture. Fish Physiology. 1998; 39: 223-303.

Ihering RV, Azevedo P. A curimatã dos açudes nordestinos (Prochilodus argenteus). Arq. Inst. Biol. 1934; 5: 143-184.

Ihering RV, Azevedo P. As piabas dos açudes nordestinos (Characidae, Tetragonopterinae). Arq. Inst. Biol. 1936; 7: 75-106.

Komen J, Richter CJ. Sex control in carp. In: Muir JF, Roberts RJ, editors. Recent advances in aquaculture IV. London: Blackwell Scientific Publications; 1993. p. 78-86.

Marcon L. Morfologia ovariana no lambari Astyanax bimaculatus sob efeito do hormônio de crescimento [M.Sc. Thesis]. Viçosa, Brasil: Universidade Federal de Viçosa; 2008.

McAndrew BJ. Sex control in tilapiines. In: Muir JF, Roberts RJ, editors. Recent advances in aquaculture IV. London: Blackwell Scientific Publications; 1993. p. 87- 98.

Mélard C. Production of a high percentage of male offspring with 17 -ethynylestradiol sex-reversed Oreochromis aureus. I: Estrogen sex-reversal and production of F2 pseudofemales. Aquaculture. 1995; 130: 25-34.

Melo FCSA, Maldonado IRSC, Benjamin LA, Matta SLP. Biologia reprodutiva de fêmeas de lambari-prata Astyanax scabripinnis (Characidae: Tetragonopterinae) em tanques de piscicultura. Rev. Ceres. 2005; 52 (304): 811-829.

Miranda ACL. Reprodução de Astyanax bimaculatus lacustris em viveiros e estudo histológico e ultraestrutural da atresia folicular de A. bimaculatus lacustris e Leporinus reinhardti em gaiolas de aquicultura [M.Sc. Thesis]. Belo Horizonte, Brasil: Universidade Federal de Minas Gerais; 1996.

Navarro RD, Silva RF, Ribeiro-Filho OP, Calado LL, Rezende FP, Silva CS, Santos LC. Comparação morfometrica e índices somáticos de machos e fêmeas do lambari prata (Astyanax scabripinnis Jerenyns, 1842) em diferente sistema de cultivo. Zootecnia Trop. 2006; 24 (2): 165-176.

Nomura H. Fecundidade, maturação sexual e índice gonadossomático de lambaris do gênero Astyanax, Baird and Girard, 1854 (Osteichthys, Characidae), relacionados com fatores ambientais. Rev. Bras. Biol. 1975; 35 (4): 775-798.

Pelizaro MG. Características macro e microscópicas do aparelho reprodutor do Astyanax bimaculatus (Linnaeus, 1758), durante o ciclo reprodutivo [M.Sc. Thesis]. São Paulo, Brasil: Universidade Estadual Paulista; 1980. 
Pereira-Filho HP. Biologia reprodutiva de fêmeas de lambari-prata, Astyanax scabripinnis, 1842 (Characidae: Teleostei) em condições de cativeiro [M.Sc. Thesis]. Viçosa, Brasil: Universidade Federal de Viçosa; 2000.

Piferrer F. Endocrine sex control strategies for the feminization of teleost fish. Aquaculture. 2001; 197: 229-281.

Piferrer F, Donaldson EM. Gonadal differentiation in coho salmon, Oncorhynchus kisutch, after a single treatment with androgen or estrogen at different stages during ontogenesis. Aquaculture. 1989; 77: 251-262.

Porto-Foresti F, Castilho-Almeida RB, Foresti F. Biologia e criação do lambari-do-rabo-amarelo (Astyanax altiparanae). In: Baldisserotto B, Gomes LC, editors. Espécies nativas para piscicultura. Santa Maria: UFMS; 2005. p. 105-120.

Porto-Foresti F, Oliveira C, Foresti F, Castilho-Almeida RB. Cultivo do Lambari: Uma espécie de pequeno porte e grandes possibilidades. Panor. Aquic. 2001; 11 (67): 15-19.

Rubin DA. Effect of $\mathrm{pH}$ on sex ratio in Cichlids and a Poecilliid (Teleostei). Copeia. 1985; 1: 233-235.

Sá MFP, Fragoso-Moura EN, Fenerich-Verani N, Ferro DAM. Occurrence of intersexuality in "lambaris", Astyanax scabripinnis (Jenyns, 1842), small characids from the brazilian streams. Braz. Arch. Biol. Technol. 2008; 51 (2): 315-322.

Sales DS, Firetti R. Rastreabilidade com alta tecnologia na piscicultura. Anualpec. 2003; 10: 323-325.
Sato Y, Sampaio EV, Fenerich-Verani N, Verani JR. Biologia reprodutiva e reprodução induzida de duas espécies de Characidae (Osteichthyes, Characiformes) da bacia do São Francisco, Minas Gerais, Brasil. Rev. Bras. Zool. 2006; 23 (1): 267273.

Scott AG, Penman DJ, Beardmore, JA. The 'YY' supermale in Oreochromis niloticus (L.) and its potential in aquaculture. Aquaculture. 1989; 78: 237251.

Strussmann CA, Takashima F, Toda K. Sex differentiation and hormonal feminization in pejerrey Odontesthes bonariensis. Aquaculture. 1996; 139: 31-45.

Veregue AML, Orsi ML. Biologia reprodutiva de Astyanax scabripinnis paranae (Eigenmann) (Ostheichthyes, Characidae), do ribeirão das Marrecas, bacia do rio Tibagi, Paraná. Rev. Bras. Zool. 2003; 20 (1): 97-105.

Wallace RA, Selman K. Cellular and dynamic aspects of oocyte growth in teleosts. Amer. Zool. 1981; 21 (2): 325-343.

Wasserman GJ, Afonso LOB. Validation of the acetocarmine technique for evaluating phenotypic sex in nile tilapia (Oreochromis niloticus) fry. Cienc. Rural. 2002; 32 (1): 133-139. 